\title{
Oral Submucous Fibrosis: An Overview
}

\author{
${ }^{1}$ Ramandeep S Narang, ${ }^{2}$ Anterpreet Arora
}

\begin{abstract}
Oral submucous fibrosis (OSMF) is a chronic and potentially malignant condition of the oral cavity. It occurs predominantly in India and Southeast Asia. The pathogenesis of OSMF is not well established, but it is believed to be multifactorial. Chewing of betel quid (containing areca nut, tobacco, and slaked lime) has been recognized as one of the most important risk factors. It is characterized by a juxtaepithelial inflammatory reaction followed by fibroelastic changes in the lamina propria and associated epithelial atrophy. The disease affects most parts of the oral cavity as well as the upper third of the esophagus. The abnormal fibrosis causes blanching and stiffness of the mouth, with eventual immobility of the lips, cheeks, tongue, soft palate, and uvula. Treatment of OSMF is difficult; a combination drug treatment is administered. In patients with severe disease, physical therapy and/or surgery is added to drug therapy.
\end{abstract}

Keywords: Areca nut, Malignant potential, Oral submucous fibrosis, Precancerous.

How to cite this article: Narang RS, Arora A. Oral Submucous Fibrosis: An Overview. Curr Trends Diagn Treat 2017;1(1):22-26.

\section{Source of support: Nil}

Conflict of interest: None

\section{INTRODUCTION}

Oral submucous fibrosis (OSMF) is an insidious, chronic disease affecting any part of the oral cavity and sometimes the pharynx. Occasionally, it is preceded by and / or associated with vesicle formation and is always associated with a juxtaepithelial inflammatory reaction followed by progressive hyalinization of the lamina propria. The later subepithelial and submucosal myofibrosis leads to stiffness of the oral mucosa and deeper tissues with progressive limitation in opening of the mouth and protrusion of the tongue, thus causing difficulty in eating, swallowing, and phonation. ${ }^{1}$ Epithelial atrophy is marked

\footnotetext{
${ }^{1}$ Professor and Head, ${ }^{2}$ Professor

${ }^{1}$ Department of Oral and Maxillofacial Pathology, Sri Guru Ram Das Institute of Dental Sciences and Research, Amritsar Punjab, India

2Department of Anatomy, Sri Guru Ram Das Institute of Medical Sciences and Research, Amritsar, Punjab, India

Corresponding Author: Ramandeep S Narang, Professor and Head, Department of Oral and Maxillofacial Pathology, Sri Guru Ram Das Institute of Dental Sciences and Research, Amritsar Punjab, India, e-mail: narangraman@yahoo.com
}

in advanced stages of the disease. Oral submucous fibrosis is a premalignant condition associated with chewing of areca nut (betel nut). ${ }^{2}$

In 1952, Schwartz described five Indian women from Kenya with a condition of the oral mucosa, including the palate and pillars of the fauces, which he called "atrophia idiopathica (tropica) mucosae oris. ${ }^{\prime 3}$ Later, it was termed as OSMF.

\section{Epidemiology}

It occurs predominantly in India, Southeast Asia, the South Pacific Islands, and South Africa. ${ }^{4}$ Around 600 million persons consume betel worldwide, which makes betel the fourth most consumed drug after nicotine, ethanol, and caffeine. ${ }^{5,6}$

The habit is prevalent in South Asia and South Africa and is also becoming common in the Western world. Betel is composed of the areca nut (Areca catechu), the fresh leaf of betel pepper (Piper betel), spices, and calcium hydroxide (lime). ${ }^{2}$ Various areca nut mixtures, i.e., pan, mawa, and gutka, are very popular in South Asia. ${ }^{7}$ Mawa is a mixture of tobacco, lime, and areca nut. ${ }^{8}$ The prevalence rate in India varies from 0.2 to $10.9 \%$ (Table 1). ${ }^{1,8-12}$ With an increase in consumption of chewing tobacco-containing areca nut, there will likely be an increase in the prevalence of OSMF.

The precancerous nature of OSMF was first postulated by Paymaster, who observed the onset of a slow-growing squamous cell carcinoma in one-third of OSMF cases seen in the Tata Memorial Hospital, Bombay. ${ }^{13}$ Epidemiological studies have shown that OSMF is a precancerous condition with a risk of malignant transformation as high as $7.6 \%{ }^{14}$

Oral submucous fibrosis is more prevalent in males, with peak seen in the 3 rd decade of life. The most common affected site is buccal mucosa followed by palate. ${ }^{15}$

Table 1: Distribution of OSMF according to geographic location

\begin{tabular}{lll}
\hline & Place/ethnic origin & \\
Investigator and year of study & of patient & Prevalence \\
\hline Pindborg and Sirsat $(1968)^{8}$ & India/Indians & $0-0.4$ \\
Lay et al $(1982)^{9}$ & Bilugyum/Burmese & 0.1 \\
Seedat and van Wyk (1988) & Durban/Indians & 3.4 \\
Rajendran (1992) & India/Indians & 0.27 \\
Gupta et al (1998) & Gujarat, India/ & 10.9 \\
& Indians & \\
Mathew et al (2008) & Southern India/ & 2 \\
& Indians & \\
\hline
\end{tabular}




\section{ETIOLOGY}

Several etiological factors, such as chilly consumption, nutritional deficiency states, areca nut chewing, genetic susceptibility, autoimmune and collagen disorders, have been suggested to be involved in the pathogenesis of OSMF.

However, areca nut is considered to be the strongest risk factor for OSMF. The amount, frequency, and duration of chewing areca nut are clearly related to the development of this disease. ${ }^{15,16}$ Areca nut is an endosperm of the fruit of the A. catechu tree. Areca nut contains tannins of which gallotannic acid and D-catechol are important. It also contains several alkaloids, of which arecoline is most abundant, and arecaidine, guvacine, arecolidine, and guvacoline are found in small quantities. The most predominant polyphenols are catechin, flavonoids, flavan-3,4-diols, leucocyanidins, hexahydroxyflavans, and tannin. Minor polyphenols include epicatechin, gallic acid, gallotannic acid, D-catechol, and phlobatannin. The increasing use of pan masala/gutka (a mixture of tobacco, areca nut, and beetle quid) seems to be associated with an earlier age of onset of OSMF. The direct contact of the quid mixture with oral tissues results in their continuous irritation by various components, including biologically active alkaloids, tannins, catechins, and copper. ${ }^{17}$ Areca nuts also contain trace elements like copper, bromide, vanadium, manganese, and chlorine, thus exposing betel quid users to increased concentrations of potentially hazardous compounds. ${ }^{18,19}$

\section{Pathogenesis}

The pathogenesis of OSMF is not well established, although a number of possible mechanisms have been suggested. Pathogenesis is believed to involve a juxtaepithelial inflammatory reaction and fibrosis in the oral mucosa, probably due to increased cross-linking of collagen through the upregulation of lysyl oxidase activity. ${ }^{20}$ Lysyl oxidase enzyme appears to take part in the initial steps of converting soluble monomers of collagen and elastin into insoluble fibers in the extracellular matrix. Excessive collagen deposition results from the effects of areca nut, which increases collagen production (e.g., stimulated by arecoline, arecaidine) and decreases collagen degradation. $^{21-23}$ Tannins from areca nuts increase collagen fiber resistance to collagenase. ${ }^{24}$

Areca nuts contain high copper concentrations, which get liberated during consumption of areca nut. The processed form of betel nut, i.e., the freeze-dried products (pan masala, gutka, mawa), contains higher concentration of copper as compared with the raw form; this may be because of the copper that is added as a preservative. ${ }^{25,26}$ The average daily intake of copper by adults from diet in developing countries is between 0.6 and $1.6 \mathrm{mg} /$ day. ${ }^{27}$ An adult Indian, chewing areca nut daily, consumes over $5 \mathrm{mg}$ of copper/day. ${ }^{28}$ Copper plays an important role in the pathogenesis of OSMF because it stimulates collagen synthesis in oral fibroblasts and also causes upregulation of lysyl oxidase enzyme. ${ }^{29,30}$ Furthermore, elevated serum and tissue copper levels are associated with duration of areca nut chewing and severity of OSMF. ${ }^{20,31}$

\section{Clinical Features}

The period between initiation of the chewing habit and the development of clinical symptoms of OSMF varies tremendously, ranging from a few months to several decades depending on the type of areca nut consumed, duration and practice of the habit, individual susceptibility, and other factors. Early symptoms include burning sensation, especially on consuming spicy foods. Increasing pain and discomfort is associated with vesicles and ulcerations. ${ }^{32}$ There is an increased salivation with a subsequent xerostomia and defective gustatory sensation. The involved tissues become blanched, opaque, and adopt a marble-like appearance (Figs 1A and B). The
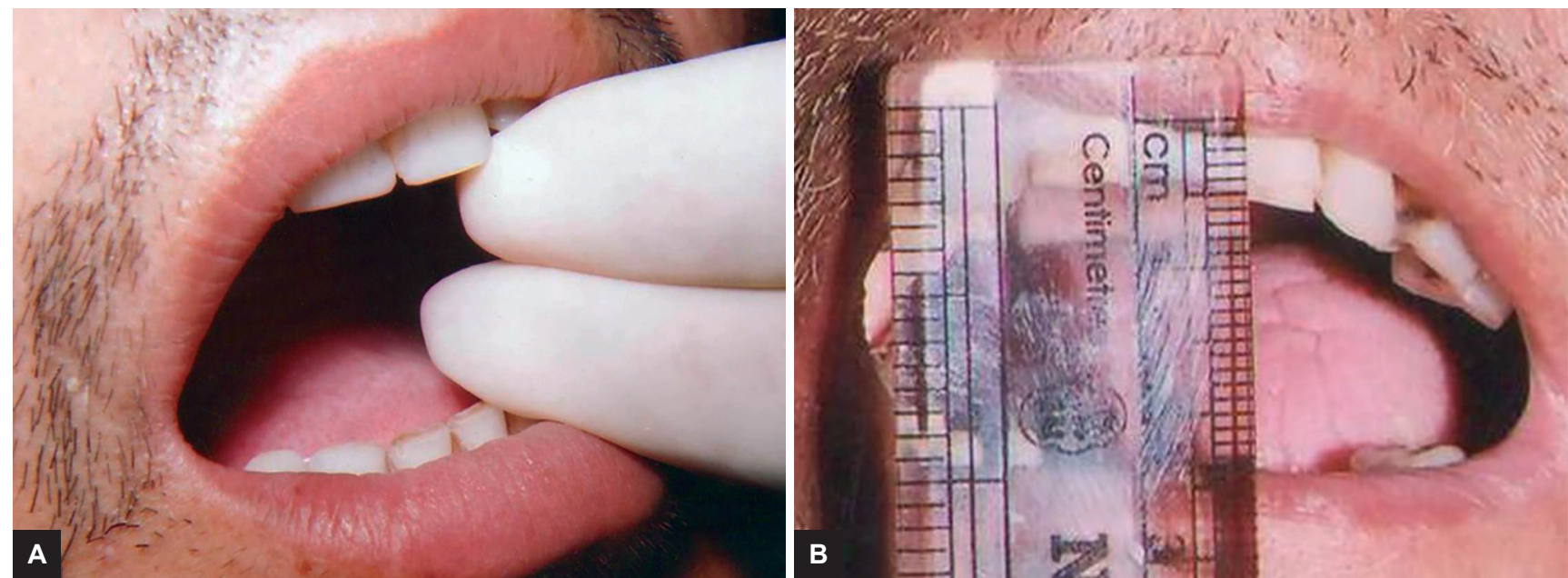

Figs $1 \mathrm{~A}$ and $\mathrm{B}$ : Extraoral photograph showing reduced mouth opening 

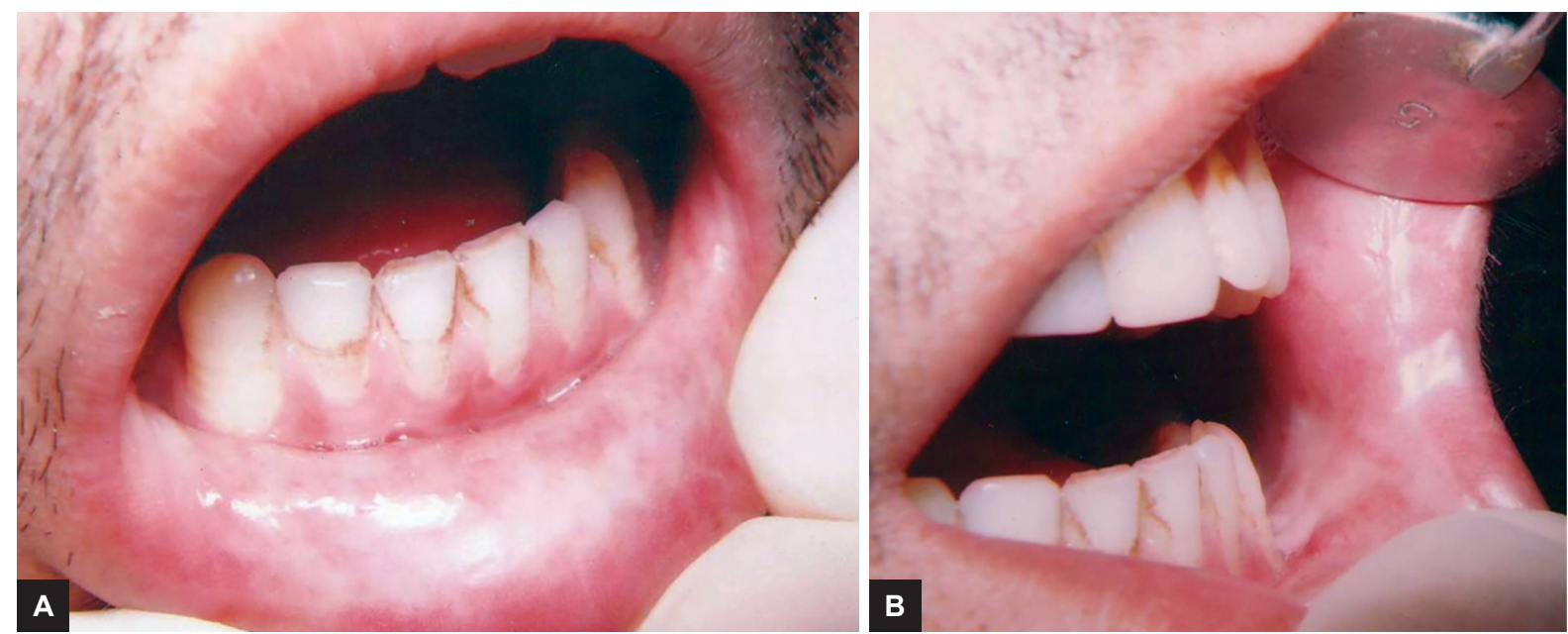

Figs 2A and B: Intraoral photograph showing blanched fibrosed oral mucosa and restricted mouth opening

figures depict blanching caused by impairment of local vascularity because of increasing fibrosis oral mucosa.

In the more advanced stage of the disease, the essential feature is a thick fibrous band, which may be palpated in the posterior buccal mucosa and around entire rima oris (Figs 2A and B). The figures depict restricting mouth opening (trismus) and causing difficulty in mastication, speech, and swallowing. The severity of trismus can be graded by measuring the interincisor opening or mouth opening. The mouth opening is categorized into stage I $(>3 \mathrm{~cm})$, stage II $(2-3 \mathrm{~cm})$, and stage III $(<2 \mathrm{~cm}) .^{33,34}$ Fibrosis makes cheeks thick and rigid. The tongue becomes progressively less mobile and there may be an associated atrophy of papillae of the tongue. Hard palate involvement includes extensively blanched mucosa. ${ }^{32}$

\section{Pathology}

It is generally agreed that the pathological alteration in OSMF begins in the lamina propria and the epithelium responds only secondarily to it. ${ }^{35}$ Based on the histopathological appearances of stained (hematoxylin and eosin) sections, the surgical specimens from OSMF can be grouped into four clearly definable stages: Very early, early, moderately advanced, and advanced. The early stages of OSMF are characterized by juxtaepithelial inflammation, including edema, large fibroblasts, and an inflammatory infiltrate, consisting primarily of neutrophils and eosinophils. ${ }^{36}$ Later, collagen bundles with early hyalinization are seen. ${ }^{37}$ In more advanced stages, OSMF is characterized by the formation of thick bands of collagen and hyalinization extending into the submucosal tissues and decreased vascularity. Muscle degeneration may also be seen in advanced stages. ${ }^{38}$ The epithelium frequently becomes atrophic and loses melanin (Figs 3A and B).

\section{Management}

So far, there does not seem to be any satisfactory treatment for OSMF, although some conservative and surgical interventions may result in improvement. ${ }^{39}$ Reduction or
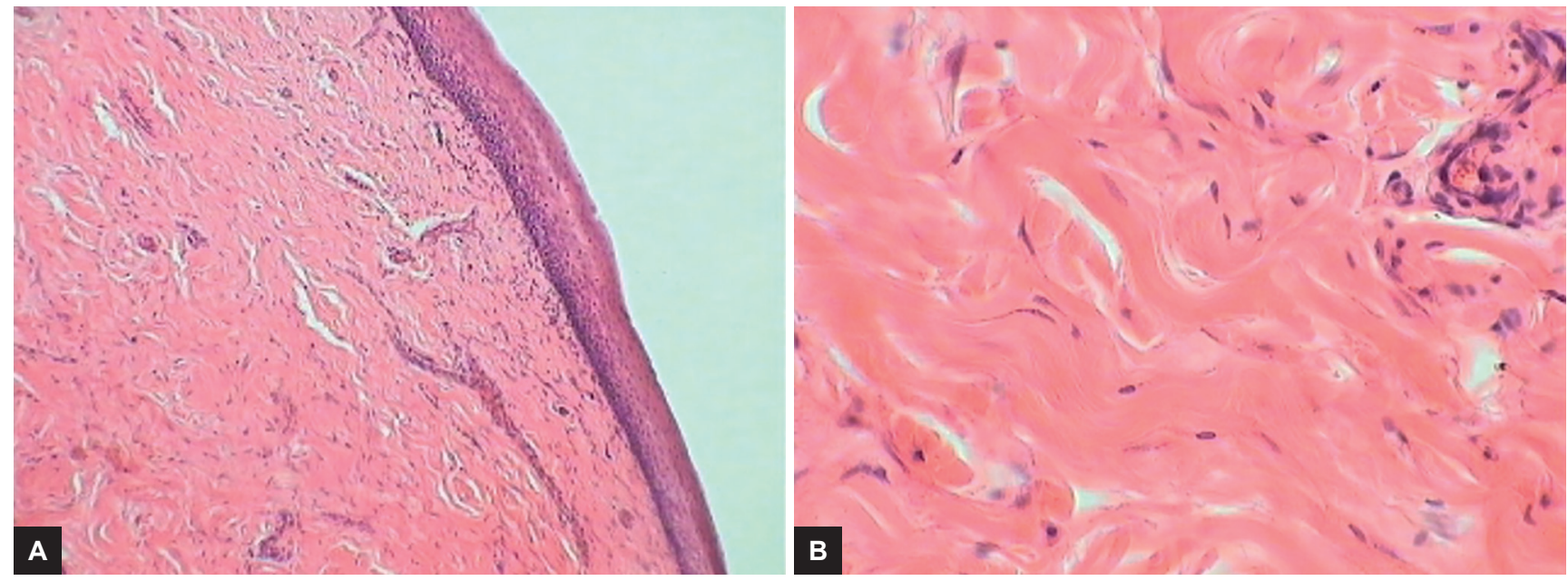

Figs 3A and B: Histology of buccal mucosa biopsy showing atrophic epithelium with thick bands of collagen bundles and decreased vascularity 
Table 2: Treatment modalities for OSMF

\begin{tabular}{|c|c|}
\hline Nutritional support ${ }^{40,41}$ & $\begin{array}{l}\text { Micronutrients and minerals, e.g., } \\
\text { Vitamins A, B complex, C, D, and } \\
\text { E, iron, copper, calcium, zinc, } \\
\text { magnesium, selenium, lycopene }\end{array}$ \\
\hline Local drug delivery ${ }^{42-44}$ & $\begin{array}{l}\text { Local injections of dexamethasone, } \\
\text { hyaluronidase, chymotrypsin, and } \\
\text { placental extract }\end{array}$ \\
\hline Physiotherapy ${ }^{43,45,46}$ & $\begin{array}{l}\text { Forceful mouth opening and heat } \\
\text { therapy in the form of hot rinses, } \\
\text { lukewarm water, or selective deep } \\
\text { heating therapies like short-wave } \\
\text { and microwave diathermy }\end{array}$ \\
\hline Surgical management ${ }^{43,47,48}$ & $\begin{array}{l}\text { Submucosal resection of fibrotic } \\
\text { bands, myotomy, coronoidectomy }\end{array}$ \\
\hline
\end{tabular}

even elimination of the habit of areca nut chewing is an important preventive measure. At least in the early stages of OSMF, it could probably slow down the progress of the disease. Currently, intralesional steroids and hyaluronidase are the main treatment modalities. Various treatment modalities for OSMF are summarized in Table 2. ${ }^{40-48}$

\section{REFERENCES}

1. Rajendran R. Oral submucous fibrosis: etiology, pathogenesis, and future research. Bull World Health Organ 1994;72(6): 985-996.

2. Wollina U, Verma SB, Ali FM, Patil K. Oral submucous fibrosis: an update. Clin Cosmet Investig Dermatol 2015 Apr;8:193-204.

3. Schwartz, J. Atrophia idiopathica (tropica) mucosae oris. Demonstrated at the Eleventh International Dental Congress, London; 1952 (cited by Sirsat and Khanolkar, Ind J Med Sci 1962;16:189-197).

4. Joshi SG. Submucous fibrosis of the palate and pillars. Ind J Otolaryngol 1953;4(1):1-4.

5. Nelson BS, Heischober B. Betel nut: a common drug used by naturalized citizens from India, Far East Asia, and the South Pacific Islands. Ann Emerg Med 1999 Aug;34(2):238-243.

6. Zain RB. Cultural and dietary risk factors of oral cancer and precancer - a brief overview. Oral Oncol 2001 Apr;37(3): 205-210.

7. Heck JE, Marcotte EL, Argos M, Parvez F, Ahmed A, Islam T, Sarwar G, Hasan R, Ahsan H, Chen Y. Betel quid chewing in rural Bangladesh: prevalence, predictors and relationship to blood pressure. Int J Epidemiol 2012 Apr;41(2):462-471.

8. Pindborg JJ, Sirsat SM. Oral submucous fibrosis. Oral Surg Oral Med Oral Pathol 1966 Dec;22(6):764-779.

9. Lay KM, Sein K, Myint A, Ko SK, Pindborg JJ. Epidemiologic study of 600 villagers of oral precancerous lesions in Bilugyun: preliminary report. Community Dent Oral Epidemiol 1982 Jun;10(3):152-155.

10. Seedat HA, van Wyk CW. Betel-nut chewing and submucous fibrosis in Durban. S Afr Med J 1988 Dec;74(11):568-571.

11. Gupta PC, Sinor PN, Bhonsle RB, Pawar VS, Mehta HC. Oral submucous fibrosis in India: a new epidemic? Natl Med J India 1998 May-Jun;11(3):113-116.

12. Mathew AL, Pai KM, Sholapurkar AA, Vengal M. The prevalence of oral mucosal lesions in patients visiting a dental school in Southern India. Indian J Dent Res 2008 Apr-Jun;19(2):99-103.
13. Paymaster JC. Cancer of the buccal mucosa: a clinical study of 650 cases in Indian patients. Cancer 1956 May-Jun;9(3): 431-435.

14. Murti PR, Bhonsle RB, Pindborg JJ, Daftary DK, Gupta PC, Mehta FS. Malignant transformation rate in oral submucous fibrosis over a 17-year period. Community Dent Oral Epidemiol 1985 Dec;13(6):340-341.

15. Pandya S, Chaudhary AK, Singh M, Singh M, Mehrotra R. Correlation of histopathological diagnosis with habits and clinical findings in oral submucous fibrosis. Head Neck Oncol 2009 May;1(1):10.

16. Rajalalitha P, Vali S. Molecular pathogenesis of oral submucous fibrosis - a collagen metabolic disorder. J Oral Pathol Med 2005 Jul;34(6):321-328.

17. Auluck A, Rosin MP, Zhang L, Sumanth KN. Oral submucous fibrosis, a clinically benign but potentially malignant disease: report of 3 cases and review of the literature. J Can Dent Assoc 2008 Oct;74(8):735-740.

18. IARC Working Group on the Evaluation of Carcinogenic Risks to Humans. Betel-quid and areca-nut chewing and some areca-nut derived nitrosamines. IARC Monogr Eval Carcinog Risks Hum 2004;85:1-334.

19. Al-Rmalli SW, Jenkins RO, Haris PI. Betel quid chewing elevates human exposure to arsenic, cadmium and lead. J Hazard Mater 2011 Jun;190(1-3):69-74.

20. Trivedy CR, Warnakulasuriya KA, Peters TJ, Senkus R, Hazarey VK, Johnson NW. Raised tissue copper levels in oral submucous fibrosis. J Oral Pathol Med 2000 Jul;29(6):241-248.

21. Shieh TY, Yang JF. Collagenase activity in oral submucous fibrosis. Proc Natl Sci Counc Repub China B 1992 Apr;16(2): 106-110.

22. Yang SF, Hsieh YS, Tsai CH, Chen YJ, Chang YC. Increased plasminogen activator inhibitor-1/tissue type plasminogen activator ratio in oral submucous fibrosis. Oral Dis 2007 Mar;13(2):234-238.

23. Chang YC, Hu CC, Lii CK, Tai KW, Yang SH, Chou MY. Cytotoxicity and arecoline mechanisms in human gingival fibroblasts in vitro. Clin Oral Investig 2001 Mar;5(1):51-56.

24. Tilakaratne WM, Klinikowski MF, Saku T, Peters TJ, Warnakulasuriya S. Oral submucous fibrosis: review on aetiology and pathogenesis. Oral Oncol 2006 Jul;42(6):561-568.

25. Mathew P, Austin RD, Varghese SS, Manojkumar AD. Estimation and comparison of copper content in raw areca nuts and commercial areca nut products: implications in increasing prevalence of oral submucous fibrosis (OSMF). J Clin Diagn Res 2014 Jan;8(1):247-249.

26. Khan S, Chatra L, Prashanth SK, Veena KM, Rao PK. Pathogenesis of oral submucous fibrosis. J Cancer Res Ther 2012 Apr-Jun;8(2):199-203.

27. Linder, MC. The bioavailability of copper. New York: Plenum Press; 1991.

28. Trivedy C, Baldwin D, Warnakulasuriya S, Johnson N, Peters T. Copper content in Areca catechu (betel nut) products and oral submucous fibrosis. Lancet 1997 May;349(9063):1447.

29. Trivedy C, Meghji S, Warnakulasuriya KA, Johnson NW, Harris M. Copper stimulates human oral fibroblasts in vitro: a role in the pathogenesis of oral submucous fibrosis. J Oral Pathol Med 2001 Sep;30(8):465-470.

30. Trivedy C, Warnakulasuriya KA, Hazarey VK, Tavassoli M, Sommer P, Johnson NW. The upregulation of lysyl oxidase in oral submucous fibrosis and squamous cell carcinoma. J Oral Pathol Med 1999 Jul;28(6):246-251. 
31. Hosthor SS, Mahesh P, Priya SA, Sharada P, Jyotsna M, Chitra S. Quantitative analysis of serum levels of trace elements in patients with oral submucous fibrosis and oral squamous cell carcinoma: a randomized cross-sectional study. J Oral Maxillofac Pathol 2014 Jan;18(1):46-51.

32. Haider SM, Merchant AT, Fikree FF, Rahbar MH. Clinical and functional staging of oral submucous fibrosis. Br J Oral Maxillofac Surg 2000 Feb;38(1):12-15.

33. Ceena DE, Bastian TS, Ashok L, Annigeri RG. Comparative study of clinicofunctional staging of oral submucous fibrosis with qualitative analysis of collagen fibers under polarizing microscopy. Indian J Dent Res 2009 Jul-Sep;20(3):271-276.

34. Patil S, Maheshwari S. Proposed new grading of oral submucous fibrosis based on cheek flexibility. J Clin Exp Dent 2014 Jul;6(3):e255-e258.

35. Rajendran R, Vijayakumar T, Vasudevan DM. An alternative pathogenetic pathway for oral submucous fibrosis (OSMF). Med Hypotheses 1989 Sep;30(1):35-37.

36. Chiang CP, Hsieh RP, Chen TH, Chang YF, Liu BY, Wang JT, Sun A, Kuo MY. High incidence of autoantibodies in Taiwanese patients with oral submucous fibrosis. J Oral Pathol Med 2002 Aug;31(7):402-409.

37. Lee CK, Tsai MT, Lee HC, Chen HM, Chiang CP, Wang YM, Yang CC. Diagnosis of oral submucous fibrosis with optical coherence tomography. J Biomed Opt 2009 Sep-Oct;14(5):054008.

38. Shafique K, Mirza SS, Vart P, Memon AR, Arain MI, Tareen MF, Haq ZU. Areca nut chewing and systemic inflammation: evidence of a common pathway for systemic diseases. J Inflamm (Lond) 2012 Jun;9(1):22.

39. Lai DR, Chen HR, Lin LM, Huang YL, Tsai CC. Clinical evaluation of different treatment methods for oral submucous fibrosis. A 10-year experience with 150 cases. J Oral Pathol Med 1995 Oct;24(9):402-406.

40. Chole RH, GondivkarSM, Gadbail AR, BalsarafS, ChaudharyS, Dhore SV, Ghonmode S, Balwani S, Mankar M, Tiwari M, et al. Review of drug treatment of oral submucous fibrosis. Oral Oncol 2012 May;48(5):393-398.

41. Kumar A, Bagewadi A, Keluskar V, Singh M. Efficacy of lycopene in the management of oral submucous fibrosis. Oral Surg Oral Med Oral Pathol Oral Radiol Endod 2007 Feb;103(2):207-213.

42. Borle RM, Borle SR. Management of oral submucous fibrosis: a conservative approach. J Oral Maxillofac Surg 1991 Aug;49(8): 788-791.

43. Gupta D, Sharma SC. Oral submucous fibrosis - a new treatment regimen. J Oral Maxillofac Surg 1988 Oct;46(10):830-833.

44. Singh M, Niranjan HS, Mehrotra R, Sharma D, Gupta SC. Efficacy of hydrocortisone acetate/hyaluronidase vs triamcinolone acetonide/hyaluronidase in the treatment of oral submucous fibrosis. Indian J Med Res 2010 May;131:665-669.

45. Cox S, Zoellner H. Physiotherapeutic treatment improves oral opening in oral submucous fibrosis. J Oral Pathol Med 2009 Feb;38(2):220-226.

46. Canniff JP, Harvey W, Harris M. Oral submucous fibrosis: its pathogenesis and management. Br Dent J 1986 Jun;160(12): 429-434.

47. Chang YM, Tsai CY, Kildal M, Wei FC. Importance of coronoidotomy and masticatory muscle myotomy in surgical release of trismus caused by submucous fibrosis. Plast Reconstr Surg 2004 Jun;113(7):1949-1954.

48. Aziz SR. Lack of reliable evidence for oral submucous fibrosis treatments. Evid Based Dent 2009 Mar;10(1):8-9. 